\title{
ENGLISH ETYMOLOGIES FROM THE POPULAR REGISTER (III)'
}

Keywords: English etymology, lexical transfers, cue, luck, shyster

\begin{abstract}
Difficulties in tracing the etymology of lexical isolates and loans from other languages are exemplified in the discussion of a gathering of English words previously without satisfactory explanations of origin.
\end{abstract}

Shyster: The OED offers this definition of shyster from a late-nineteenth century American dictionary, since the term is judged by its earliest attestations (1840s) to have originated in North America:

A lawyer who practices in an unprofessional or tricky manner; especially, one who haunts the prisons and lower courts to prey on petty criminals; hence, any one who conducts his business in a tricky manner. (OED s.v. shyster; accessed 1 September, 2015) $)^{2}$

Recalling the law court environment of pun Sayers (2014) and related but now in a North American context, shyster is located to the register of slang. As to etymology, the OED states only "of obscure origin", while offering a tentative clue: 'It might be $<$ shy adj. (sense 7, disreputable) + -ster' but goes on to add 'this sense of the adj. is apparently not current in the U.S.'

The first attestation of shyster in the English of North America is found in George Wilkes's The Mysteries of the Tombs, a journal of thirty days imprisonment in the New York City Prison, from 1844, in the phrase "inferior shysters" (Wilkes 1844: 44).

1 This article concludes an inquiry initiated under the same title in volume 133, issues 3 and 4 of this journal.

2 The definition is drawn from Funk's standard dictionary of 1895 (Funk, March 1895). 
A more telling comment, also located to the "Tombs" (the Halls of Justice in lower Manhattan, under construction from 1835) is found in George G. Foster, New York in slices: "He must ... wait next day for the visits of the 'shyster' lawyers - a set of turkey-buzzards whose touch is pollution and whose breath is pestilence." (Foster 1849: 20) $)^{3}$

The OED's shy 'disreputable' does seem ruled out as a source for shyster but shy in the U.S. sense of 'short of, lacking' ("I'm shy twenty dollars") could be adduced, although it would have been more likely the accused who were short of money rather than the advocates who sought to represent them for what would have been a fee within their possibly strained means. Despite some popular associations (perhaps, inter alia, with the name Shylock), shyster is not drawn from Yiddish. The documented alternative spelling, shuyster, suggests not only some uncertainty as to the vowel quality but also a possible origin in a German or Dutch family name (cf. Germ. Schuster 'shoemaker'), one of whose members became sufficiently notorious, like a Lynch or Boycott, as to give rise to a collective designation that entered mainstream speech.

However, an alternative and more plausible origin for the word may be sought in another of the immigrant languages of nineteenth-century New York City, more exactly Irish. In Irish, seist (with an initial [sh-] sound) referred to 'talk, speech' and, by extension, 'tumult, bustle' - a neat juxtaposition, if one has the busy corridors and rooms of the Tombs in mind (Dinneen 1927, s.v. seist). This could have combined with the common Irish agent suffix -aire to give seistaire 'spokesperson, advocate'. Words such as mobster and gangster might be imagined as having had a shaping influence - overriding, as it were, the history of the suffix -ster as the marker for a female agent - but the former is not attested in the U.S. as 'member of a criminal gang' until 1917 and the latter is first met there in $1896 .{ }^{4}$ If the above etymology were to command credence, one would have to envisage, over time, some pejoration in semantics, the advocate of the prisoner being tarred with the same brush of malfeasance as the accused.

Cue: The OED defines cue as 'the concluding word or words of a speech in a play, serving as a signal or direction to another actor to enter, or begin his speech'. The etymology is called "uncertain", this judgment authorized by the following commentary in the new online version of the dictionary:

It has been taken as = French queue tail (see cue n. $\left.{ }^{3}\right)$, on the ground that it is the tail or ending of the preceding speech; but no such use of queue has ever obtained in French (where the cue is called réplique), and no literal sense of queue or cue leading up to this appears in 16th cent. English. On the other hand, in 16th and early 17th cent. it is found written $Q, q, q$., or $q u$, and it was explained by 17 th cent. writers as

On the Tombs, see Gilfoyle (2003).

4 The OED has an informative entry for the suffix -ster (accessed 1 September, 2015). 
a contraction for some Latin word (sc. qualis, quando), said to have been used to mark in actors' copies of plays, the points at which they were to begin. But no evidence confirming this has been found. (OED, s.v. cue, n. ${ }^{2}$; accessed 1 September, 2015)

While it is certainly true that early modern French queue was not used in a theatrical or dialogic context, its medieval Anglo-French congeners, cowe, queüe, et al., had a wide variety of significations: 'tail; scut' (of hare or deer); 'end, tail' (of plants); 'train' (of dress); 'end' (of plough, pan); 'hilt' (of sword); 'wick'; 'seal-strip of document' (bearing the seal or name of addressee); (figuratively) 'scrap, bit'. ${ }^{5}$ In a legal context, queue was also used for what English jurisprudence has called the 'foot of fine', where 'fine' represents 'a final agreement: an amicable composition or agreement of a suit, either actual or fictitious, by leave of the king or his justices' (Blackstone). ${ }^{6}$ The more frequent term for this "foot" in Anglo-French legal lexis and the source of the English phrase was pee (Mod. Fr. pied) and in Anglo-Latin, pes. The OED finds the origin of the metaphor "foot of fine" in the spatial disposition of the document of agreement:

... foot of a fine ... that one of the 'parts' of a tripartite indenture recording the particulars of a fine ... which remained with the court, the other two being retained by the parties. When the undivided sheet was placed so that this counterfoil could be read, it was actually at the 'foot' of the parchment; ... in the other two counterparts the direction of writing was at right angles to that of the 'foot'. (OED, s.v. foot, 20; accessed 1 September, 2015) ${ }^{7}$

In Randle Cotgrave's French-English dictionary of 1611 is found the entry: queüe 'the labelle of a deed', vital evidence for the survival of the medieval Anglo-French term into what has been called Law French (Cotgrave 1650, s.v. queüe).

If the original tripartite format of the indenture were modified over time into the simple "top to bottom" layout of modern documents, with no rotation of a section of text, it may be speculated that the third portion or archival copy, that to be retained by the court, was introduced in some cases by an appropriate marker in the form of the letter Q. ${ }^{8}$ If we can further imagine the transfer of this rebus-like symbol from one vocal public arena to another, that is, from the courts to the stage,

5 Rothwell et al. (2005), s.v. cowe; recorded spellings are cowe, cow; coue, couhe, coune, couwe; coe, cue; keu, keue, koe, kou, kouhe, kouwe, kowe, kue, kuwe; que, queue and reflect a lively oral use of the term, nearly independently of French orthographical antecedents. Anglo-French is also recognized as the origin of cue as 'the long straight tapering rod of wood tipped with leather, with which the balls are struck in billiards and similar games' (OED, s.v. cue, n. $\left.{ }^{3}\right)$. The $O E D$ goes on to note 'according to Littre the queue was originally the small end of the tapering stick then called the billard'.

6 In an exchange recorded in the year books of Edward III, a clerk is said to open the fine and the judge then asks "Coment parle la cowe?" ('What does the foot (lit. tail) say?'); Pike (1883-1911: 6. 457).

7 On the practice of recording such final accords, see further Clanchy (1993).

8 We have no evidence for the relative frequency over time of pee and queue, both designating the 'foot' of the agreement. Pee would appear to have won out, given the foot of early modern English. 
Q could have been similarly employed, as alleged, in personal or loaned copies of a script, to distinguish parts in a manuscript. The individual actor would have so marked his own copy, as did the King's court, as that of prime importance. Once on stage, it would have been the spoken and heard concluding lines of one actor that became the operative cue for a fellow-player to begin to speak.

The development here proposed for cue is only conjectural and no manuscript evidence from court records in Britain's National Archives or working copies of dramatic scripts have thus far been exhumed to support it. It does, however, suggest a clue to follow in future research into cue. ${ }^{9}$ The city is the site of both fortune and misfortune, turns of fate with which the central body of this essay concludes.

Luck: The OED traces luck in the sense of 'fortune good or ill; the fortuitous happening of events favourable or unfavourable to the interests of a person' to Low German luk (with comparable forms in Dutch and Old Frisian), which is, in turn, a shortened form of geluk (Middle Dutch gelucke = Middle High German gelücke, modern German glück). Noting apparent parallel adoptions of the Low German word in Icelandic lukka (14th c.), Middle Swedish lukka, lykka (modern Swedish lycka), Danish lykke, the dictionary concludes that luck "probably ... came into English as a gambling term; the Low German dialects were a frequent source of such terms in 15-16 centuries" (OED, s.v. luck, n.; accessed 1 September, 2015). In the more ample commentary that is one of the great advantages of the online edition of the $O E D$, the discussion pursues the German connection:

The ultimate etymology of Middle High German gelücke (< Old High German ${ }^{*}$ giluc$c h i<$ Old Germanic type ${ }^{*}$ galukkjo-m) is obscure. ... Formally, the word might be cognate with [English] louk v.1 or louk v.2, or with German locken to entice (Old High German lockôn) and the synonymous Old High German lucchen; but no probable hypothesis seems to have been formed to connect the meaning of the noun with that of any of these verbs. (OED, s.v. luck, n.; accessed 1 September, 2015)

A connection with German gelingen (Old High German gilingan) 'to succeed, turnout well or ill' is rejected on morphological grounds. The present note pursues the $O E D$ 's suggestion of a possible association with English louk in the meaning 'to close, shut, fasten', a word with well attested antecedents in Old English but edging into obsolescence by the early seventeenth century.

In Old Norse the regular meaning of luk $k$ (past participle lokinn), cognate with Old English lúca, is 'to close, end, finish' (Cleasby et al. 1957, s.v. lúka). It is used of material depletion, for example, a store of food being used up, and in reference to closing apertures such as doors, gates, and hatches. In literary texts it is used

9 On the National Archives holdings of feet of fines, see http://www.nationalarchives.gov.uk/ records/research-guides/land-conveyance-feet-of-fines.htm. As concerns these two potential signals, just as the term cue may have originated on vellum, clue (earlier clew) has its origins in the technologies of wool and yarn; see OED (s.v. clue; accessed 1 September, 2015). 
preferentially of the conclusion and outcome of dynamic human relations, in particular of legal proceedings, after charges and rebuttals have been projected against the impersonal gridwork of the law and a judgment reached. As well, lúka occurs when men's individual destinies are seen under the aegis of a similarly distant fate. ${ }^{10}$

A leit-motif of charges, adjudication, and legal closure runs through the Icelandic Njáls saga, although this does not similarly check human emotions or feuding. It is realized in the narrative through the verb luk $a$ and, in particular, through the present passive form lúkast 'will be settled, be resolved, turn out'. A typical instance is when Gunnar has sought to settle the bickering initiated by his wife Hallgerðr and Njáll's wife Bergpóra but finds that contention nonetheless escalates, with the result that Gunnar finds himself obliged to kill a man. At this level of seriousness the matter is taken to the Thing. The saga introduces the assembly: "Er um petta allfjölrætt á pingi hversu pessi mál mundu lúkast." (Einarr 1933: Ch. 73), 'The time came for the Thing, and both sides came in large numbers. There was much talk how this case would turn out' (Cook 2002: Ch. 73). Other sagas, such as Egils saga, offer comparable evidence for the use of luka/lúkast in reference to a settlement still to be made, an outcome that cannot be predicted with assurance (Nordal 1933: Ch. 81-82).

English translations of the various Norse collocations with luk $a$ fail to retain the concrete central image of impersonal closure without reference to human interests and desires. From a rhetorical perspective, this impedes the ready recognition of the Norse concept's role in the creation of English luck. Some examples: "var pess ván, at illa mundi illum lúka" - 'that it would end badly with a bad man'; "svá lauk at lyktun" - 'finally it ended so that'; "ádr lýkr" - 'before the end comes'; "lúka upp gørð” - 'to deliver a judgment'; "skal nú yfir lúka með oss" - 'now it will come to an end, to a final issue with us' (examples cited from Zoëga 1910, s.v. lúka, reflecting Cleasby et al. 1957). While not always an acceptable translation option, the idea of "how things will fall out" is fairly close in both semantic valence and affect to the Norse phrasings. The figures of the sagas have a keen sense of the contingent in human life and of arbiters more distant than human judges but it would be imprudent to extrapolate from what is, in part, surely a literary and genre convention and try to tie lúka/lúkast too closely to notions of fate and destiny. ${ }^{11}$

Although used in figurative applications, such as closing one's heart, Old English lúca is not found in this sense of circumstances being locked down in irremediable fashion or of an unpredictable outcome being delivered. ${ }^{12}$ According to the OED, the earliest attestation in English letters of luck in its current sense is in Caxton's translation of the story of Reynard the Fox ("Tho thought reynart, this is good

10 Further exemplification and discussion of ON lúka in Sayers (2016).

11 Note too the use of the ON verb skipta 'to change, exchange' but also 'to bring to an end', used in reference to fateful outcomes, and skop 'what is fated, one's fate'; brief discussion in Bek-Pedersen (2011: 17-18). A rather different basic image is seen in ON ørlogi 'fate, doom, fortunes', the singular of which is ørlygi 'fight, war'.

12 Dictionary of Old English (di Paulo-Healy et al. 1986-) has not yet reached the letter L. 
luck"). ${ }^{13}$ That it could mean luck good or bad is evident in Palsgrave's dictionary entry: 'Lucke, happe, hevr', cf. later French bonheur, malheur (Palsgrave 1530: 241/1). More pointed is the pairing from Fleming's translation of Sulpicius: "It was his hard lucke \& curssed chaunce, ... to finde ..." (Fleming 1576: 39).

The proposal of a loan of Old Norse lúka must be made with a number of reservations. With the exception of lúkning 'discharge, payment', Old Norse has preserved no nominal form related to the ideas of good and ill fortune, a more likely tentative antecedent for English luck than a verb. Such a loan would also have had to remain submerged in the Anglo-Norse speech of the Danelaw and northern Britain for some centuries, retaining its specific semantics, which included fateful outcomes, and a distinct phonological profile, which evolved as luck, while remaining separate from its English cognate lúca, which developed as louk. ${ }^{14}$ This said, Old Norse lúka is a more plausible source for English luck than the vagaries of port-town gambling and card-playing among speakers of Low German and English. This is the more evident when one recognizes that the OED has played Etymology with a stacked deck and that all the cited early Germanic parallels from the time when a borrowing might have occurred, e.g., MLG luk, meant not 'luck', good or bad, but exclusively 'good luck'. ${ }^{15}$

The baker's dozen of words examined in this three-part study, which have no inherent affiliation and are gathered only to illustrate some of the problems which attend the study of the origins of words isolated in a greater vocabulary, are all called by the $O E D$ of uncertain, doubtful, or unknown origin. The search capacities of the OED Online permit the word buff to compile lists of words so designated - and, for the etymologist, to create a lifetime's agenda. Yet happenstance, serendipidity, and

13 From 1481, Caxton (1970: 15). Middle English dictionary (Kurath et al. 2001) has two entries for $l u k$ from about the same period.

14 There is no known derivative of Norse lúka in the Norman dialect of French. Although beyond the professed ambit of this journal, attention may be briefly called to a single instance of loux in an Anglo-Norman collection of proverbs based on a Latin original (Sanson de Nanteuil 1988-1994: 8101). In a typical contrast between the pious and impious, Solomon is believed to have said: "Proz hom manguet dunt il vit E s'alme refait de delit. E le ventre as felons est loux Ke ja n'en ert pleins ne saoux" ('The good man eats that of which he lives and his soul is filled with pleasure; and the belly of the wicked is loux for it is never full nor sated from it \{eating\}; Rothwell et al. 2005) tentatively translates the hapax loux as 'insatiable' but this would result in some semantic duplication, which is not, however, foreign to medieval writing. Old Norse lúka was used with the prepositional adverbs upp and aptr in collocations signifying not closure but aperture, 'to open up, unlock'; cf. ON lúka ' hollow hand'. Thus, Norman loux (arguably < the ON stem lúk-, with the regular loss of the intervocalic or final consonant $k$ ) could have meant 'empty', i.e. 'opened up' and thus 'void'.

15 See, for example, Mittelniederdeutsches Wörterbuch (Köbler 2014) s. vv. gelücke, gelükke, gelük, glük, glückke 'Glück, Schicksal, günstiger Zufall, glückliches Geschick, Vorteil' and lūke, luke 'durch eine Klappe verschließbare Öffnung', e.g. 'Luke im Schiffdeck, Luke auf dem Hausboden, Luke als Kelleröffnung'. The distant root of all the Germanic terms is, however, the same as that of ON lúka; see Köbler (1995, s.v. Glück). 
the idiosyncratic aura given off by the individual word may well be a more satisfying avenue of approach to the huge vocabulary of unpedigreed English. In addressing the many words in English still without satisfactory etymologies, it may always be possible to redact relatively full notes like those assembled here but the greater amplitude of entries now possible with electronic versions of our standard lexicographical reference works will also permit, at a single, highly accessible site, a fuller discussion of etymologies and, equally importantly, the history of vocabulary over time, not least in the critical area of semantic evolution. In this call for a renewed historicization of vocabulary, many challenges remain.

As for early modern English, it seems undeniable, on the basis of this sample of lexis and other word studies conducted by the author, that the impact of Irish and Irish English on the urban speech of England was considerably greater in the sixteenth to eighteenth centuries than presently acknowledged. This impact is particularly apparent in the speech of the courts and its client classes, including the criminal underclass, and in the fashionable language of "men about town". The borrowed vocabulary, marked by imagery and word-play, more often than not deals in intangibles - obnoxious behaviour, fashion - rather than, say, the natural world, artifacts, or technologies, such as those of the farm and crafts. Transcultural loans of single lexemes are an important group of words that may subsequently develop in isolation in the host language. Most of these words were accommodated in the English sound system and in English semantics in ways that mask their origins but also add a slight or slightly greater pejorative affect, an apparent carry-over from their "baser" origins. Many vogue words must not have survived into modern English. In conclusion, the contributions to our word-hoard of Irish and Scots Gaelic, and speech that was once called cant, slang, vulgar, obscene, etc. must not be given short schrift in the print and electronic dictionaries of the future. ${ }^{16}$

\section{References}

Bek-Pedersen K. 2011. The Norns in Old Norse mythology. Edinburgh.

Caxton W. (transl.). 1970. The history of Reynard the fox. Oxford.

Clanchy M. 1993. From memory to written record: England 1066-1307. [2 $2^{\text {nd }}$ edition]. Malden (Maine).

Cleasby R., Gudbrand V., Craigie W. (eds.). 1957. An Icelandic-English dictionary. [2 ${ }^{\text {nd }}$ edition]. London.

Cook R. (transl.). 2002. Njal's saga. London.

Cotgrave R. 1650. A French-English dictionary. London.

Dinneen P. (ed.). 1927. Foclóir Gaedhilge agus Béarla - an Irish-English dictionary. Dublin.

di Paulo-Healy A. et al. (eds.). 1986-. Dictionary of Old English. Toronto.

Einar Ó.S. (ed.). 1933. Brennu-Njáls saga. Reykjavík.

Fleming A. (transl.). 1576. A panoplie of epistles. London.

Foster G. 1849. New York in slices. New York.

Funk I., March F. (eds.). 1895. A standard dictionary of the English language. London, New York.

16 This line of thought is more fully developed in Sayers (2008). 
Gilfoyle T. 2003. 'America's greatest criminal barracks': The Tombs and the experience of criminal justice in New York City, 1838-1897. - Journal of Urban History 29: 525-554.

Köbler G. (ed.). 1995. Deutsches etymologisches Wörterbuch. [www.koeblergerhard.de/ derwbhin.html].

Köbler G. (ed.). 2014. Mittelniederdeutsches Wörterbuch. [www.koeblergerhard.de/mnd wbhin.html].

Kurath H. et al. (eds.). 2001. Middle English dictionary. Ann Arbor (Michigan).

National Archives (Great Britain). [www.nationalarchives.gov.uk].

Nordal S. (ed.). 1933. Egils saga. Reykjavík.

OED = Oxford English Dictionary. 1989-2014. Oxford. [OED online: http://www.oed.com/]. Palsgrave J. 1530. Lesclarcissement de la langue francoyse. London.

Pike L. (ed. and transl.). 1883-1911. Year Books of the Reign of King Edward the Third. London. Rothwell W. et al. (eds.). 2005. Anglo-Norman dictionary. [2 ${ }^{\text {nd }}$ edition]. London.

Sanson de Nanteuil. 1988-1994. Les proverbes de Salemon. [edited by C. Isoz]. London.

Sayers W. 2008. Contested etymologies of some English words in the popular register. Studia Neophilologica 80: 15-29.

Sayers W. 2014. Pun, quibble, carwitchet, clench. - ANQ 27.2: 55-58.

Sayers W. 2016. Norse Loki as praxonym. - Journal of Literary Onomastics 5.1: 17-28.

Wilkes G. 1844. The mysteries of the Tombs, a journal of thirty days imprisonment in the New York City Prison. New York.

Zoëga G. (ed.). 1910. Concise dictionary of Old Icelandic. Oxford. 